\title{
Peningkatan Kualitas Program Pashmina Melalui Pengkajian Kebutuhan Remaja
}

\author{
Sri Sumaryani ${ }^{1}$, Aswad Ishak ${ }^{2}$ \\ 1. Program Studi Ilmu Keperawatan, Fakultas Kedokteran dan IImu Kesehatan, Universitas Muhammadiyah Yogyakarta, Jl Brawijaya \\ Geblagan, Tamantirto, Kec. Kasihan, Yogyakarta, Daerah Istimewa Yogyakarta 55183 \\ 2 Program Studi Ilmu Komunikasi, Fakultas ilmu Sosial dan Ilmu Politik, Universitas Muhammadiyah Yogyakarta, Jl Brawijaya Geblagan, \\ Tamantirto, Kec. Kasihan, Yogyakarta, Daerah Istimewa Yogyakarta 55183 \\ Email: srisumaryani@umy.ac.id \\ DOI: $10.18196 / p p m .39 .124$
}

\begin{abstract}
Abstrak
Masa remaja merupakan masa transisi perkembangan fisik, mental, dan reproduksinya yang dapat berdampak pada status kesehatan remaja tersebut. Status kesehatan remaja dipengaruhi oleh perkembangan teknologi informasi. Kemudahan akses informasi dan teknologi dapat berdampak buruk bagi remaja apabila remaja tidak memiliki bekal pengetahuan yang baik dan memadai. Nasyiatul Aisyiyah hadir dengan program Pelayanan Remaja Sehat Milik Nasyiatul Aisyiyah (PASHMINA) untuk menjawab beberapa kasus pada remaja. Program Pengabdian Kepada Masyarakat ini bertujuan untuk meningkatkan kapasitas pengetahuan kader dalam melakukan screening atau pengkajian kesehatan reproduksi remaja. Metode yang digunakan adalah model pemberdayaan masyarakat partisipatif yaitu dengan melibatkan para kader PASHMINA dalam setiap program yang telah direncanakan berupa analisis kebutuhan dan penyedian alat-alat yang digunakan untuk melakukan screening kesehatan pada remaja, pelatihan pengkajian pada remaja dengan melihat proses pengkajian secara langsung dan pelibatan kader dalam pengkajian kebutuhan pendidikan kesehatan reproduksi remaja. Hasil dari kegiatan ini adalah peningkatan pemahaman kader PASHMINA terkait kebutuhan pendidikan kesehatan reproduksi remaja remaja dan keterampilan teknik pengkajian untuk penggalian isu-isu sensitif pada remaja. Implikasi dari kegiatan ini diharapkan mampu meningkatkan kemampuan para kader dalam implementasi program. Kesimpulan dari kegiatan ini adalah adanya peningkatan kapasitas kader dalam melakukan screening kesehatan pada remaja terutama kemampuan untuk melakukan pengkajian pada remaja
\end{abstract}

Kata Kunci: Nasyiatul Aisyiyah, PASHMINA, Kader, Pengkajian

\section{Pendahuluan}

Masa remaja merupakan masa transisi perkembangan fisik, mental, dan reproduksinya yang dapat berdampak pada status kesehatan remaja tersebut. Status kesehatan remaja dipengaruhi oleh perkembangan teknologi informasi. Kemudahan akses informasi dan teknologi dapat berdampak buruk bagi remaja apabila remaja tidak memiliki bekal pengetahuan yang baik dan memadai. Perkembangan informasi dan teknologi dapat mempengaruhi perilaku remaja termasuk perilaku merokok, dan penggunaan obat-obat terlarang, dan bahkan perilaku seksual berisiko. Permasalahan tumbuh kembang remaja dengan tantangan zaman yang harus mereka hadapi, membutuhkan perhatian dan penyelesaian yang tidak bisa dianggap sederhana. Perkembangan teknologi informasi dan kemudahan akses yang belum berbanding lurus dengan kesiapan remaja beserta stakeholders di sekitarnya untuk memanfaatkan secara proporsional serta akulturasi dan pergeseran budaya yang semakin tak terbendung, menjadi faktor penyebab tergerusnya nilai-nilai luhur yang seharusnya menjadi kepribadian dan karakter remaja. Berbagai variasi kasus dan persoalan yang melibatkan remaja, justru terjadi akibat ketidaktahuan mereka tentang tugas perkembangan yang harus dipenuhi akibat perubahan fisik dan psikologis yang berpengaruh pada permasalahan kesehatan reproduksi.

Nasyiatul 'Aisyiyah dengan gerakan Ramah Perempuan dan Anak merasa perlu mengambil peran untuk membantu para remaja yang membutuhkan konsultasi, informasi dan edukasi tentang diri mereka, dengan memberikan akses informasi dan pelayanan kesehatan sederhana yang mudah dijangkau oleh remaja. PASHMINA (Pelayanan Remaja Sehat milik NA) adalah salah satu program dari Nasyiatul 'Aisyiyah untuk menjalin komunikasi dengan remaja melalui pelayanan keagamaan, kesehatan, konsultasi psikologi dan edukasi. 
Urgensi PASHMINA bagi remaja adalah sebagai berikut: 1 . Remaja merupakan individu yang sedang dalam masa transisi kanak-kanak menuju dewasa. Pada masa ini, remaja mengalami perkembangan fisik, psikologis dan sosial. Perkembangan fisik meliputi: perubahan payudara pada perempuan, perubahan suara pada pria, tumbuh jakun dan sebagainya. 2. Pada aspek psikologis, remaja sering mengalami rasa kecewa dan tidak stabil secara emosi, sedangkan secara sosial mudah terpengaruh teman yang memiliki sifat dan kualitas psikologis yang sama dengan dirinya, misal hobi, minat, sikap, nilai-nilai dan kepribadiannya. Perkembangan yang cukup rawan pada remaja adalah sikap conformity, yaitu kecenderungan untuk menyerah dan mengikuti bagaimana teman sebayanya, termasuk dalam praktik gaya hidup negatif yang mempengaruhi kepribadian remaja. (Pimpinan Pusat Nasyiatul Aisyiah, 2015) Ruang lingkup Kegiatan PASHMINA meliputi upaya pengembangan remaja dan kesehatan remaja yang mencakup upaya edukatif-preventif, konsultatif, partisipatif dan rekreatif. Berikut ini adalah penjelasan tentang ruang lingkup kegiatan PASHMINA: a) Edukatif-preventif, diwujudkan dalam seluruh aspek kegiatan, bahwasanya PASHMINA sebagai wadah berkumpul remaja merupakan arena belajar. Dalam setiap pos mengandung unsur gizi. edukasi untuk remaja, serta pencegahan atas diri remaja pada perilaku, kondisi, dan lingkungan yang tidak sehat. b) Konsultatif, komunikasi dalam pelayanan pos PASHMINA bersifat dua arah, di mana setiap petugas pos memiliki kewajiban untuk membuka diri pada remaja, menerima, dan berbagi cerita serta keluh kesah remaja. Tidak hanya itu saja, sebagai wadah remaja maka PASHMINA juga menjadi ajang berbagi antar peserta. c) Partisipatif, dalam PASHMINA, pelayanan dilaksanakan oleh tenaga kesehatan dan penggerak remaja. Kegiatan dilakukan berdasarkan pendekatan partisipasi remaja dan masyarakat disesuaikan dengan kondisi dan potensi remaja setempat d) Rekreatif, sesuai dengan karakter remaja yang dinamis aktif, mudah bosan, maka PASHMINA menjadi wadah remaja yang nyaman, dan menjadikan remaja bisa mengaktualisasikan serta mengekspresikan diri. (Pimpinan Pusat Nasyiatul Aisyiah, 2015)

Pelayanan PASHMINA masih mengalami banyak kendala antara lain peralatan yang belum mencukup baik secara jumlah maupun kualitas dan masih kurangnya kemampuan kader PASHMINA untuk melakukan pengkajian terkait kesehatan reproduksi remaja terutama kemampuan menggali isu-isu yang sensitif. Tim pengabdian masyarakat membantu memberikan solusi pada PCNA Bantul dan PRNA Ringinharjo dalam implementasi pelayanan PASHMINA tersebut dengan menyediakan alat dan melatih para kader PASHMINA agar handal dalam melakukan pengkajian dan pemeriksaan sederhana sesuai program PASHMINA. Kegiatan yang dilakukan oleh tim pengabdian terdiri dari pemberian hibah alat kesehatan dan pelatihan kepada para kader untuk menggali atau melakukan pengkajian pada remaja terkait kesehatan reproduksi.

\section{Metode Pelaksanaan}

Metode yang digunakan dalam kegiatan ini adalah model pemberdayaan masyarakat partisipatif atau Participatory Rural Apraisal (PRA). Metode PRA dipilih berdasarkan pertimbangan bahwa yang mempunyai atau menghadapi masalah adalah mitra, oleh karena itu keterlibatan mitra dalam penentuan pemecahan masalah dan penyelesaiannya sangat diperlukan. Metode tersebut dibagi menjadi 3 tahap yaitu persiapan, pelaksanaan, dan penyusunan laporan

Upaya dalam mengatasi permasalahan mitra dilaksanakan dengan langkah-langkah sebagai berikut:

\section{Tahap Persiapan}


1. Tim pengabdian bersama mitra merumuskan tindakan atau intervensi prioritas untuk membantu mengatasi permasalahan mitra dalam hal ini para kader PASHMINA

2. Tim pengabdian masyarakat menyiapkan format pengkajian pada remaja

3. Tim pengabdian masyarakat bersama mitra menentukan waktu dan tempat pelaksanaan

4. Mitra pengabdian masyarakat mengirimkan undangan untuk target sasaran (kader PASHMINA)

5. Mitra pengabdian menyiapkan tempat, setting, dan media

\section{Tahap Pelaksanaan}

1. Penyediaan peralatan untuk melakukan pengkajian dan pemeriksaan fisik sederhana yang dilakukan dengan cara pemberian dana untuk pembelian alat-alat pemeriksaan

2. Pelibatan kader PASHMINA pada proses pengkajian permasalahan kesehatan reproduksi remaja di SMP Muhammadiyah Bambanglipuro yang dilaksanakan pada bulan September 2020. Demonstrasi pengkajian pada remaja dilakukan pada 8 remaja laki-laki

3. Zoom meeting untuk memberikan materi tambahan terkait cara-cara atau teknik pengkajian pada remaja melalui teknik komunikasi yang diikuti oleh 10 kader PASHMINA

4. Melaksanakan role play untuk melakukan pengkajian pada remaja yang diwakili oleh 2 orang kader melalui online

\section{Hasil dan Pembahasan}

Hasil dari kegiatan pengabdian masyarakat ini adalah tersedianya alat-alat untuk membantu proses pengkajian atau screening kesehatan remaja. Alat-alat tersebut digunakan oleh para kader dalam memberikan pelayanan PASHMINA. Ketersediaan alat dalam bentuk kuantitas dan kualitas mampu memberikan manfaat kepada kader PASHMINA dalam mengimplementasikan program kerja. Selain penambahan jumlah alat untuk melakukan screening kesehatan pada remaja, kegiatan pengabdian kepada masyarakat ini juga mampu memberikan gambaran nyata dalam menggali pemahaman, permasalahan-permasalahan dan kebutuhan remaja mengenai kesehatan reproduksi. Kader dapat menyaksikan langsung teknik komunikasi pada remaja agar remaja mau memberikan informasi yang akurat tentang pemahaman mereka terkait kesehatan reproduksi. Proses pelibatan kader dalam melakukan pengkajian pada 8 remaja SMP Muhammadiyah Bambanglipuro telah mampu memberikan tambahan pengetahuan, pemahaman dan keterampilan para kader dalam pengkajian terutama teknik komunikasinya agar remaja mau terbuka dengan pemahamam dan permasalahan yang remaja hadapi. Peningkatan aspek kognitif pada kader kesehatan mengenai teknik pengkajian melalui peningkatan skills komunikasi pada remaja sangat penting dan menjadi salah satu tujuan dalam kegiatan ini mengingat dari berbagai penelitian yang telah dilakukan didapatkan bahwa aspek pengetahuan merupakan hal yang memengaruhi perilaku seseorang. Pengetahuan merupakan hasil dari tahu, dan ini terjadi setelah orang melakukan pengindraan terhadap suatu objek tertentu. Pengindraan terjadi melalui pancaindra manusia, yakni indra penglihatan, pendengaran, penciuman, rasa, dan raba. Sebagian besar pengetahuan manusia diperoleh melalui mata dan telinga. Pengetahuan atau kognitif merupakan domain yang sangat penting dalam membentuk tindakan seseorang (overt behavior) (Notoatmodjo, 2012), termasuk dalam hal ini tindakan kader kesehatan dalam melakukan screening atau pengkajian pada remaja terkait kebutuhan informasi dan permasalahan kesehatan reproduksi. 
Selain aspek kognitif, aspek psikomotor merupakan salah satu aspek yang sangat penting bagi kader kesehatan dalam melakukan perannya sebagai salah satu sumber informasi kesehatan. Aspek psikomotor merupakan aspek yang berkaitan dengan keterampilan atau kemampuan bertindak setelah seseorang menerima pengalaman belajar tertentu. Hasil belajar aspek psikomotor ini tampak dalam bentuk keterampilan dan kemampuan bertindak individu. Hasil belajar psikomotor ini sebenarnya merupakan kelanjutan dari hasil belajar kognitif (memahami sesuatu) dan hasil belajar afektif (yang baru tampak dalam bentuk kecenderungankecenderungan berperilaku) (Simpson, 2008). Target aspek psikomotor yang dicapai dalam kegiatan ini kader kesehatan mampu melakukan screening atau pengkajian pada remaja, melakukan teknik komunikasi dengan benar, dan memberikan edukasi pada remaja yang membutuhkan konsultasi. Hasil kegiatan menunjukkan bahwa seluruh peserta memiliki kemampuan komunikasi efektif dalam kategori baik. Selain itu, seluruh peserta PKM juga memiliki motivasi untuk melakukan pengkajian pada remaja terkait permasalahan dan kebutuhan informasi mengenai kesehatan reproduksi. Motivasi merupakan hal yang sangat penting dan menjadi salah satu luaran dalam kegiatan ini. Motivasi adalah sebuah alasan atau dorongan seseorang untuk bertindak. Alasan atau dorongan itu bisa datang dari luar maupun dari dalam diri (Samsudin, 2005). Sebenarnya pada dasarnya semua motivasi itu datang dari dalam diri, faktor luar hanyalah pemicu munculnya motivasi tersebut (Samsudin, 2005). Motivasi dari luar adalah motivasi yang pemicunya datang dari luar diri kita. Sementara motivasi dari dalam ialah motivasinya muncul dari inisiatif diri kita. Selanjutnya, Samsudin (2005) memberikan pengertian motivasi sebagai proses memengaruhi atau mendorong dari luar terhadap seseorang atau kelompok agar mereka mau melaksanakan sesuatu yang telah ditetapkan. Motivasi juga dapat diartikan sebagai dorongan (driving force) dimaksudkan sebagai desakan yang alami untuk memuaskan dan mempertahankan kehidupan.

\section{Simpulan}

Kader PASHMINA mengalami peningkatan kemampuan dalam melakukan screening atau pengkajian pada remaja terutama pengkajian mengenai kebutuhan remaja terkait informasi dan permasalahan reproduksi.

\section{Ucapan Terima Kasih}

Penulis menyampaikan terimakasih kepada Lembaga Penelitian dan Pengabdian kepada Masyarakat Universitas Muhammadiyah Yogyakarta dan Bapak Ibu Guru SMP Muhammadiyah Bambanglipuro yang telah memfasilitasi kegiatan pengabdian ini

\section{Daftar Pustaka}

1. Badan Kependudukan dan Keluarga Berencana Nasional. 2018. Survei Demografi dan Kesehatan Indonesia 2017. Jakarta, Indonesia.

2. Dinkes DIY. 2018. Profil Kesehatan Daerah Istimewa Yogyakarta Tahun 2018. Yogyakarta, Indonesia. www.dinkes.jogjaprov.go.id.

3. Notoatmodjo, S. (2012). Ilmu kesehatan masyarakat: Prinsip-prinsip dasar. Jakarta: Rineka Cipta.

4. Samsudin, S. (2005). Manajemen sumber daya manusia. Bandung: Pustaka Setia.

5. Surahman, Hanifa Kasih; Netraningrum, Endah Marbenis; Wulandari, F. Buku Panduan PASHMINA. S. Irmawati, ed. Jakarta, Indonesia: Pimpinan Pusat Nasyiatul Aisyiyah. nasyiah.or.id. 